\title{
Measuring residual feed intake in dairy heifers fed an alfalfa (Medicago sativa) cube diet
}

\author{
G. C. Waghorn, ${ }^{1}$ K. A. Macdonald, ${ }^{*}$ Y. Williams, $\dagger$ S. R. Davis, $\dagger^{2}$ and R. J. Spelman $\ddagger$ \\ *DairyNZ Ltd., Private Bag 3221, Hamilton, Waikato, 3240 New Zealand \\ †Department of Primary Industries, Private Bag 1, 255 Ferguson Rd., Tatura, Victoria 3616, Australia \\ łLivestock Improvement Corporation, Research and Development, Private Bag 3016, Waikato, 5200 New Zealand
}

\section{ABSTRACT}

Selection for divergence between individuals for efficiency of feed utilization (residual feed intake, RFI) has widespread application in the beef industry and is usually undertaken when animals are fed diets based on silages with grain. The objective of this research was to develop a feeding system (using Gallagher, Hamilton, New Zealand, electronics) to measure RFI for growth in Holstein-Friesian heifers (aged 5-9 mo), and identify divergent individuals to be tested for RFI during lactation. A dry forage diet (alfalfa cubes) was fed because intakes could be measured accurately, and the New Zealand dairy industry (4.4 million milking cows in lactation) relies heavily on forage feeding. The evaluation was undertaken over 3 yr with 1,052 animals fed in a facility for $7 \mathrm{wk}$, and weighed 3 times weekly. The mean age at the start of measurements was $215 \mathrm{~d}$, body weight $(\mathrm{BW}) 189 \mathrm{~kg}$, and mean daily dry matter intakes averaged $6.7 \mathrm{~kg}$. Body weight gain (all animals) averaged $0.88 \mathrm{~kg} / \mathrm{d}$. The RFI was determined as the residuals from the regression of mean intake on mean $\mathrm{BW}^{0.75}$ and daily BW gain of individuals. Actual and fitted intakes were strongly related $\left(\mathrm{R}^{2}=0.82\right)$. In terms of gross efficiency (feed intake/BW gain), RFI + year explained $43 \%$ of the variation, BW gain + year explained $66 \%$, and RFI + BW gain + year explained $79 \%$ of the variation (all $P<0.001$ ). Daily BW gains $(\mathrm{kg})$ of the most and least efficient $10 \%$ averaged $( \pm$ standard deviation) $0.88 \pm 0.15$ and $0.88 \pm 0.12(P=$ $0.568)$, respectively, and the divergence between mean intakes was $1.46 \mathrm{~kg}$ of dry matter $/ \mathrm{d}$. The most and least efficient animals will be tested for RFI during lactation and genetic markers will be identified for the trait.

Key words: residual feed intake, Holstein heifer, alfalfa cube

Received June 30, 2011.

Accepted October 6, 2011.

${ }^{1}$ Corresponding author: Garry.waghorn@dairyNZ.co.nz

${ }^{2}$ Current address: ViaLactia Biosciences, PO Box 109185 , Newmarket 1149, Auckland, New Zealand.

\section{INTRODUCTION}

Feed accounts for more than $50 \%$ of direct costs for milk production in most dairy operations, including TMR systems in the United States (Williams and Jenkins, 2006; Herndon et al., 2010) and pastoral grazing in New Zealand (DairyBase, 2011). A sound economic basis exists for lowering feed costs while maintaining animal health and production, and this may be achieved by selecting animals that use feed more efficiently. Selection to identify individuals with energy requirements that are less than the population mean (low residual feed intake, RFI) has been applied to pigs (Barea et al., 2010), poultry (Van Eerden et al., 2004), mice (Nielson and McDonald, 2006), and beef cattle (e.g., Basarab et al., 2003; Arthur and Herd, 2005; Lancaster et al., 2009; Shaffer et al., 2011), but less often to dairy cattle (Veerkamp and Emmans, 1995; Berry, 2009; Williams et al., 2011). Selection for divergence in RFI identifies efficient and inefficient individuals that may be retained or removed from the population, respectively. The requirements for selection are measurement of feed consumed, and production - either BW gain or milk. These are achieved relatively easily when grainand silage-based diets are fed because feed volumes are small, the DM percentage is relatively constant and automated weighing in conjunction with individual electronic identification (EID) can easily determine feed eaten by individuals (e.g., Arthur and Herd, 2005).

Measuring RFI in cattle using grain- and silagebased rations is appropriate when commercial feeding is based on similar diets. The New Zealand dairy industry is based on ryegrass pasture, which accounts for about $90 \%$ of DMI for the average cow (Holmes et al., 2002). Adaptation by New Zealand Holstein-Friesian cattle, which account for about $42 \%$ of the dairy herd (LIC, 2009), to pastoral feeding has resulted in quite different phenotypes compared with Holsteins raised under confined systems with TMR in North America (Harris and Kolver, 2001; Kolver et al., 2002). Most apparent are the larger size and higher milk production in dairy cattle fed grain-based diets, and an inability to consume sufficient fresh forage at grazing to meet 
requirements for lactation (Kolver and Muller, 1998), resulting in a low BCS and reproductive failure (Macdonald et al., 2008; Lucy et al., 2009). Adaptation to a forage diet through selection, and differences between strains in behavior (Thorne et al., 2003), digestion, and metabolism (Waghorn, 2002; Herd and Arthur, 2009) have prompted measurements to identify individuals with divergent RFI to be based on a forage diet, namely alfalfa (Medicago sativa) cubes. This dry diet (without concentrate) facilitated feeding and intake measurements, and fiber length was adequate to support normal rumen function.

Divergent RFI is largely independent of production level or product composition (Arthur and Herd, 2005), although minor differences have been reported in subcutaneous fat depth (Shaffer et al., 2011), especially when fat is a high proportion of gain (Lancaster et al., 2009). Gains in efficiency are a consequence of decreasing the energy costs of maintenance and the synthesis of product (carcass or milk). In lactating dairy cows producing 20 to $40 \mathrm{~kg}$ of milk/d, about 20 to $40 \%$ of daily ME intake is retained in the milk (Primary Industries Standing Committee, 2007), so gains in efficiency can only be made in 60 to $80 \%$ of the ME intake used for maintenance and milk synthesis. However, over a lifetime, these opportunities become substantial, especially in seasonal dairying where lactation length may be 260 to $280 \mathrm{~d} /$ annum, and constrained by pasture availability (Holmes et al., 2002). Efficient individuals will require less feed for maintenance during dry (nonlactating) periods and during growth to first lactation.

A summation of energy costs in pastoral grazing systems (Holmes et al., 2002), for a cow (450 kg mature weight) producing $350 \mathrm{~kg}$ of milksolids (fat + protein)/ annum $(4,575 \mathrm{~kg}$ of milk containing $4.5 \%$ fat and $3.5 \%$ protein) over 5 lactations at pasture, suggests an annual ME intake of about 45,500 MJ, of which 14,800 MJ are in the milk. Estimated energy requirement for growth to first calving $(24 \mathrm{mo}$ ) is $30,000 \mathrm{MJ}$ of $\mathrm{ME}$, with 8,500 MJ retained in body tissues (Holmes et al., 2002). Over a 7-yr lifespan and 5 lactations, about 77,900 MJ of ME will be recovered in milk (and carcass; 0.45 of BW) from a total intake of 258,000 MJ of ME. Significant opportunities exist for improved efficiencies through selection of efficient (low RFI) dairy cattle, because only $30 \%$ of energy intake is retained in product and $70 \%$ is associated with maintenance and product synthesis. Johnson et al. (2003) concluded that potential existed for up to about $12 \%$ increases in the efficiency of $\mathrm{ME}$ use for maintenance.

The research presented here was undertaken with a view to identifying genetic marker(s) for RFI in dairy cows, and the research was carried out in association with a similar trial in Australia (Williams, et al., 2011).
The decision to evaluate 2,000 cows was based in part on simulations by McNaughton and Pryce, (2007) to determine the likelihood of estimating genotypic and phenotypic variation from a range of population sizes, and constraints associated with the costs of screening. It was not possible to measure RFI in 2,000 lactating cows, so the measurements were made with young (prepubertal) dairy heifer calves (weaners) and RFI determinations were based on daily BW gain, with $10 \%$ low and 10\% high RFI animals retained for verification of the trait as lactating animals.

The decision to use BW gain as a proxy for lactation RFI was based on 2 main premises: (1) lifetime feed intake for New Zealand pasture-fed cattle results in about $70 \%$ of feed energy being used for purposes other than product. This is based on calculations (above) for typical dairy cows in New Zealand (LIC, 2009), and efficiencies will apply to maintenance and energy used for tissue synthesis during growth and milk synthesis. (2) Most evidence supports digestion and biochemical bases for divergent energy requirements (Waghorn and Dewhurst, 2007; Herd and Arthur, 2009) and differences in energy needs will be equally applicable to energy used for maintenance and synthetic processes, but not energy in product, for young and mature animals. The efficiency of energy use in the synthesis of milk from pasture diets, assumed to be 0.60 to 0.65 (Primary Industries Standing Committee, 2007), will benefit from more efficient energy capture from improved digestion of feed (Nkrumah et al., 2006; Waghorn and Dewhurst, 2007).

Requirements for RFI measurement include accurate records of intake, production, and ensuring that selection is based on animals with appropriate genetic merit for production. The duration of trials is often determined by the need for accurate measurements of daily gain, and this is complicated by variation in BW associated with rumen fill (Archer et al., 1997; Kearney et al., 2004), and in the work presented here, animal weighing frequency was evaluated to determine a balance between shorter trial duration and disruption to animal feeding by removal for weighing.

This report describes the processes used for determining divergence in RFI in 1,052 young dairy cattle in New Zealand and summarizes the outcomes from the trial. Data from this work and that of Williams et al. (2011), undertaken in Australia, have been used to determine genetic predictions of RFI and calculation of heritabilities for RFI and 250-d BW (Pryce et al., 2012).

\section{MATERIALS AND METHODS}

Measurements of RFI were undertaken over a 3-yr period (commencing 2008), with measurements from 
164 animals in yr 1, followed by 444 in yr 2 and 3. Measurement of RFI with 444 heifers required sequential feeding in the facility, which can accommodate 224 individuals ( 28 pens, each holding 8 individuals).

In yr 2 and 3, 448 animals were selected for evaluation, but failure to adapt to conditions, or misadventure resulted in removal of 4 individuals in each year. The selection was from about 480 to 500 available for purchase, and ensured that any small or sick animals could be excluded.

Procurement of each group of 448 animals required about 300 contacts be made to potential suppliers [members of Livestock Improvement Corporation (LIC), a farmer-owned artificial breeding cooperative] that had bred appropriate dams and sires (breed and genotype). Calf procurement was based around birth dates, and 2 groups about $35 \mathrm{~d}$ apart were secured for the sequential evaluations in the facility. This range in mean birth dates is the feasible maximum under the New Zealand seasonal calving pattern.

Calves for each evaluation ( $\mathrm{n}=164-224)$ were grazed in single groups from weaning until measurements began in the feeding facility, and then until calving at $2 \mathrm{yr}$ of age. Prior to placement in the pens, animals were offered cubes when grazing for $4 \mathrm{~d}$, so they were accustomed to the diet when allocated (randomly) to pens. Mean age when placed in the facility was between 177 and $213 \mathrm{~d}$. This trial was approved by the Ruakura Animal Ethics Committee (AEC 11385).

\section{Calf Procurement and Selection}

The process for procuring the calves commenced with identification of farmers using artificial breeding (with LIC) in a $100-\mathrm{km}$ radius of the rearing facility. Letters were sent to about 300 farmers outlining the intent, and farmer acceptance of offers was about $60 \%$. About 1,850 contracts were signed for right to purchase, but only about 480 were purchased from these contracts. A typical breakdown of outcomes, with approximate losses (\%) and calf numbers is summarized in Table 1.

All animals were of Holstein-Friesian parentage (15/16 or better) with a breeding worth of over 170 (LIC, 2009) to represent typical herd values in 2018. Selection was based on the LIC database, which enabled parentage to be checked against farmer AI records. Breeding worth is a ranking system (AEU, 2011) based on expected genetic ability to breed profitable and efficient replacements, and relates mainly to cow progeny. The breeding worth ranking is based on cow ancestry, her own lactation performance, and progeny information for 7 traits: production of milk protein, fat, milk weight, somatic cells, BW, fertility, and residual survival (longevity), all of which are combined with specific economic values to derive a breeding worth (AEU, 2011). These traits are combined, and the breeding worth is expressed as net lifetime income (\$NZD) per $4.5 \mathrm{t}$ of $\mathrm{DM}$ feed required. This value is increasing for the national herd, consequent upon sire selection, evaluation of daughters by herd test, and use of artificial breeding.

Female calves were collected within 4 to $7 \mathrm{~d}$ of birth, assessed for general health, given a unique identification (ID) tag, weighed, and measurements (tape) taken of girth, height, and length. A blood sample $(10 \mathrm{~mL}$ into heparinized Vacutainers, Becton, Dickinson and Co., Franklin Lakes, NJ) was taken from the jugular vein to check that the calf was free of bovine viral diarrhea, and an ear notch tissue sample was collected for parentage testing (GeneMark, LIC) and future DNA analysis.

\section{Calf Rearing}

Calves were fed colostrum as per normal farm practice and raised in groups of 50 by a commercial calf rearer. Rearing was based on milk with access to calf meal, according to standard commercial practice (Macdonald et al., 2007). At about $7 \mathrm{~d}$ of age, milk was fed 2 times daily and then once daily, with a gradual reduction in milk availability after $5 \mathrm{wk}$ of age and complete withdrawal of milk by $95 \mathrm{~kg}$ (10 wk of age). Calves were weighed weekly until weaning, and vaccinated with a 5 -in-1 vaccine at 5 wk to provide protection against clostridial diseases. Fecal egg counts for gastrointestinal nematodes were made from a subsample of calves at 10 wk to determine the prevalence of gastrointestinal parasitism and all animals were drenched with anthelmintic when egg count exceeded 1,500/g of feces.

At about 10 wk of age, the calves were transported to a property where they were grazed on perennial ryegrass dominant swards until they entered the feeding facility

Table 1. Breakdown of farmer contacts, calf procurement, and calf losses to meet requirements for residual feed intake (RFI) evaluation with 448 heifers in cohorts $2 \mathrm{a}$ and $2 \mathrm{~b}$, and $3 \mathrm{a}$ and $3 \mathrm{~b}$

\begin{tabular}{lc}
\hline $\begin{array}{l}\text { Factors affecting } \\
\text { calf procurement } \\
\text { with percentage loss }\end{array}$ & $\begin{array}{c}\text { Number of } \\
\text { animals }\end{array}$ \\
\hline Initial contracts & 1,850 \\
Contingency, 10\% & 1,665 \\
Cows not mated by AI, 25\% & 1,250 \\
Females, 48\% & 600 \\
Twins, 2\% & 588 \\
Under 30-kg BW, 5\% & 560 \\
Death at calving, 5\% & 535 \\
Unresolved parentage, 7\% & 500 \\
Loss before weaning, 3\% & 486 \\
Postweaning loss and other problems, $3 \%$ & 470 \\
Reserve, $5 \%$ & 448 \\
\hline
\end{tabular}


at 6 to $8 \mathrm{mo}$ of age. They were weighed at 6 weekly intervals during this time. Following the measurements to determine RFI, they were returned to the same grazing property. Future evaluation of these animals will include determination of RFI during lactation.

\section{The Feeding Facility and Data Acquisition}

The 28-pen facility was constructed from concrete and galvanized steel pipe. Each pen was $42 \mathrm{~m}^{2}$ and the bedding comprised coarse wood shavings on top of stones and drainage pipes. The pens included gates enabling animals to be confined onto a concrete apron $(2 \times 6 \mathrm{~m})$ so that manure could be removed from the bedding area $(6 \times 6 \mathrm{~m}$ of wood shavings $)$ and, on occasion, the shavings replaced. Maintenance was undertaken daily. The facility was not covered, but shade cloth provided animals some protection from wind and sun. A single feeding station was available within each pen, accessible to 1 animal at a time and the feed bin was mounted on load cells. Bin weight and animal ID were recorded continuously when accessing the cubes, so intake, time, and duration of eating were recorded. Water was freely available, as was trace mineralized salt in a block (Dominion Salt Ltd., Mount Maunganui, New Zealand).

Access to the feed was restricted to 1 animal at a time via a narrow chute and individual ID was recorded by an EID reader (Gallagher G03103 R series; Gallagher Group Ltd., Hamilton, New Zealand) mounted above the feed bin. The bins were constructed from molding polythene, and were $(\mathrm{cm}) 90$ high $\times 90$ wide $\times 85$ deep, angled (rear and sides) to a $65 \times 65 \mathrm{~cm}$ base held on a platform over load cells. Four load cells supported each bin and weights were recorded at 0.02 -s intervals to an accuracy of $0.1 \mathrm{~kg}$.

Data acquisition (Gallagher G01100 SmartScale $300 / 400$ ) involved a network of 14 scales based on an RS485 protocol and the EID readers. Scales and RS485 converters were powered by $12-\mathrm{V}$ direct current supplies. Two computers (14 scales per computer) stored the data and software had been developed to acquire, interpolate, and present data in 4 levels of detail. The whole system is able to recover from power failure unassisted and maintain operation in the event of a short (up to $5 \mathrm{~min}$ ) power failure.

Levels of data acquisition/presentation were level 1: all bin weights and EID, data logged every second (about $200 \mathrm{MB} / \mathrm{d}$ ); level 2: event recording, associated with EID recognition $(10 \mathrm{MB} / \mathrm{d})$; level 3: interpretive summary of all weight/EID events, including dates and times, duration of meal, intake rates, length of eating bout, session interval (unoccupied time) daily summary of unaccounted feed weights. This file was used for data analysis $(0.2 \mathrm{MB} / \mathrm{d})$; and level 4: bin weights every 30 $\mathrm{s}(2.5 \mathrm{MB} / \mathrm{d})$.

\section{Feeding and Intakes}

Alfalfa cubes (7/8 inch; 22 -mm side) were supplied by Kapt-Al Grain \& Storage Ltd. (Vancouver, BC, Canada). Following their introduction at pasture, the cubes were fed as a sole diet for an 11-d acclimatization period in the facility, followed by the 49-d measurement period. Feeding was usually once daily, with cubes dispensed from a front-mounted $1.2-\mathrm{m}^{3}$ auger bucket (Pearson Engineering Ltd., Matamata, New Zealand) and took about 30 min for the 28 bins. Feed was available to the animals for more than $22.5 \mathrm{~h}$ per day.

Although intakes were recorded for each animal, the values were checked daily to ensure accuracy. Validation was based on both whole-pen and individual-animal data. Whole-pen data were checked by comparing cumulative values for each meal with daily disappearance from bins. The processes (software assisted) enabled reconciliation of individual totals within $24 \mathrm{~h}$, with full and empty bin weights. A variance exceeding $4 \%$ required investigation, which included an examination of variation in daily intakes for individuals, followed by manual checking of data if necessary. Individual animal data were checked to identify daily intakes that differed by $20 \%$ (or more) from 3 previous daily means. Very high $(>15 \mathrm{~kg} / \mathrm{d})$ or low $(<3 \mathrm{~kg} / \mathrm{d})$ intakes were checked, as well as eating rates exceeding $1 \mathrm{~kg} / 5 \mathrm{~min}$, or negative values.

Care was taken to ensure valid bases for exclusion, and incorrect values were removed. Poor reconciliation of data was uncommon and usually related to occasional failure in electronics (water in connections) or faulty load cell performance, with occasional failure or interference in animal EID. Data were removed in about 750 of 55,000 animal-days of recording.

\section{Weighing}

Body weight was recorded 3 times/wk using a commercial walk-over weigher, with a Gallagher SmartScale 500 data collector and EID reader (SmartReader HR1). Animals were held on the scale to ensure accurate readings, but the process was rapid, taking 2 to $3 \mathrm{~min}$ for each pen of 8 animals.

The decision to weigh 3 times per week did not disrupt feeding and gave an opportunity to significantly reduce the time required to measure RFI. Initial trial data (based on a daily gain averaging $1.0 \mathrm{~kg}$ and a standard deviation of $3.5 \mathrm{~kg}$ about the BW) was used to calculate the standard error of the regression for BW gain over time. These results (summarized in Table 
Table 2. Standard error of the regression for BW gain over time ${ }^{1}$

\begin{tabular}{lccccc}
\hline & \multicolumn{5}{c}{ Weighing frequency } \\
\cline { 2 - 5 } $\begin{array}{l}\text { Weeks } \\
\text { in pens }\end{array}$ & Daily & $\begin{array}{c}3 \text { times } \\
\text { per week }\end{array}$ & $\begin{array}{c}2 \text { times } \\
\text { per week }\end{array}$ & Weekly & $\begin{array}{c}\text { Every } \\
2 \text { wk }\end{array}$ \\
\hline 4 & 0.0777 & 0.1113 & 0.1291 & 0.1581 & 0.1768 \\
5 & $\underline{0.0562}$ & 0.0814 & 0.0953 & 0.1195 & 0.1768 \\
6 & 0.0430 & 0.0629 & 0.0741 & 0.0945 & 0.1118 \\
7 & 0.0343 & $\underline{0.0504}$ & 0.0598 & 0.0772 & 0.1118 \\
8 & 0.0282 & 0.0416 & $\underline{0.0495}$ & 0.0646 & 0.0791 \\
9 & 0.0237 & 0.0351 & 0.0419 & $\underline{0.0551}$ & 0.0791 \\
10 & 0.0237 & 0.0301 & 0.0360 & 0.0477 & $\underline{0.0598}$ \\
\hline
\end{tabular}

${ }^{1}$ Based on data from this trial assuming daily gains of $1.0 \mathrm{~kg}$ and a standard deviation of 3.5 about the BW. Calculated from daily, 3 times weekly, 2 times weekly, weekly, and every 2 wk measurements. Underlined values indicate similar standard deviations.

2) show similar standard deviations for daily, 3 times per week, 2 times per week, weekly, and every 2 wk weighing, corresponding to $5,7,8,9$, and 10 wk of measurement, respectively. Frequent weighing enabled the duration of each measurement period to be shortened substantially, compared with trials with heifers (Archer et al., 1997) or mature cattle (Kearney et al., 2004), where weighing was at 14 -d intervals.

\section{Analyses}

Subsamples of cubes were taken during each 49-d evaluation period for analysis by near infrared reflectance spectroscopy (FeedTech, AgResearch, Palmerston North, New Zealand) to determine the principal chemical components. Analysis included a prediction of $\mathrm{OM}$ digestibility and ME concentration in the DM.

The growth rate of the animals was modeled by linear regression of BW against time over the trial duration, and the regression coefficients calculated for the ADG of each animal. The mean daily feed intake was calculated for each animal over the trial period and corrected for DM content of the cubed diet.

The RFI was estimated as the residuals after multiple regression of intake on ADG $(\mathrm{kg} / \mathrm{d})$ of all animals and mean metabolic BW $\left(\mathrm{BW} \mathrm{kg}^{0.75}\right)$ at the trial midpoint. The model fitted was

$$
\mathrm{Y}_{\mathrm{int}}=\mathrm{C}+\mathrm{b} 1 \mathrm{ADG}+\mathrm{b} 2 \mathrm{BW}+\mathrm{RFI},
$$

where $Y_{\text {int }}$ is the mean daily feed intake $(\mathrm{kg}$ of $\mathrm{DM} / \mathrm{d})$, $\mathrm{C}$ is the intercept, b1 and b2 are partial regression coefficients, $\mathrm{ADG}$ is $\mathrm{kg} / \mathrm{d}$, BW is mean $\mathrm{BW}^{0.75}(\mathrm{~kg})$ at the trial midpoint, and RFI is the residual error $(\mathrm{kg} / \mathrm{d})$.

Comparisons between cohorts and most and least efficient groups $(10 \%$ with the lowest and $10 \%$ with the highest RFI) were based on ANOVA. Data from all 28 pens were combined for analysis using mixed models fitted with REML in GenStat13. The ANOVA treated cohort, group ( $10 \%$ with lowest and highest RFI), and the interaction as fixed effects and animal as a random effect.

\section{RESULTS}

One thousand and fifty-two calves were selected for this evaluation, and 1,049 completed the 49-d measurement period; removals were for an impacted abomasum, misadventure, and poor adaptation to the environment. Overall, the facilities and diet enabled feeding and measurements to be undertaken efficiently and reliably, despite the outdoor situation in a moderately windy environment where the animals had shade and some shelter, but were not able to avoid rain. The mean wind daily wind run is $344 \mathrm{~km}$, with occasional gusts exceeding $60 \mathrm{~km} / \mathrm{h}$, and annual rainfall is 1,114 $\mathrm{mm}$. Annual sunshine is about $2,100 \mathrm{~h}$ and the mean daily temperature was $12.2^{\circ} \mathrm{C}$. The hardware used for EID and recording performed adequately under these conditions and the diet comprising entirely alfalfa cubes maintained good growth rates and animal health.

Animal age at the commencement of the intake and gain measurements to determine RFI averaged $215 \pm$ $32 \mathrm{~d}( \pm \mathrm{SD})$, with 4 of the 5 groups ranging from 176 to $253 \mathrm{~d}$ of age (Table 3). Delays in commissioning the facility resulted in older animals at the commencement of measurements for cohort 1 (Table 3) than in other years. The range in average age between cohorts in yr 2 and 3 of the evaluation (48 and $51 \mathrm{~d}$ ) was unavoidable, because measurements were sequential within years, and the seasonal calving pattern in New Zealand dairy farming results in a narrow spread of calving dates (Holmes et al., 2002). Despite the variations in age, daily gains averaged for animals in each cohort ranged between 0.80 and $0.93 \mathrm{~kg} / \mathrm{d}(P<0.001$; Table 3$)$. The slower daily gain of cohort 2 a was attributed to some animals indicating Yersinia pseudotuberculosis before entering the pens. This bacterial infection is common 
Table 3. Age at the start of measurements, breeding worth, BW, daily DMI, and daily gain of animals (means \pm SD) in the 5 cohorts of Holstein-Friesian calves used to determine divergence for residual feed intake

\begin{tabular}{|c|c|c|c|c|c|}
\hline \multirow[b]{2}{*}{ Item } & \multicolumn{5}{|c|}{ Cohort } \\
\hline & 1 & $2 \mathrm{a}$ & $2 \mathrm{~b}$ & $3 a$ & $3 \mathrm{~b}$ \\
\hline Animal number & 164 & 219 & 219 & 224 & 223 \\
\hline Age at start (d) & $253 \pm 6.5$ & $186 \pm 4.8$ & $234 \pm 7.2$ & $176 \pm 9.7$ & $227 \pm 11.2$ \\
\hline Breeding worth & $143 \pm 25.4$ & $156 \pm 13.2$ & $132 \pm 13.6$ & $142 \pm 13.1$ & $141 \pm 16.0$ \\
\hline Initial BW ${ }^{1}(\mathrm{~kg})$ & $219 \pm 18.3$ & $153 \pm 15.6$ & $171 \pm 16.1$ & $157 \pm 13.3$ & $169 \pm 11.3$ \\
\hline Daily gain $(\mathrm{kg})$ & $0.88 \pm 0.14$ & $0.80 \pm 0.12$ & $0.91 \pm 0.14$ & $0.93 \pm 0.11$ & $0.84 \pm 0.11$ \\
\hline
\end{tabular}

${ }^{1}$ Initial and mid-trial BW were derived from fitted regressions over time for each animal.

in calves and associated with ill thrift. Mean BW at entry to the facility was $189 \pm 37.7 \mathrm{~kg}( \pm \mathrm{SD})$.

The cubes averaged $84.5 \pm 1.04 \% \mathrm{DM}( \pm \mathrm{SD})$ and contained $18.7 \pm 1.62 \% \mathrm{CP}( \pm \mathrm{SD}), 45.8 \pm 2.97 \% \mathrm{NDF}$ $( \pm \mathrm{SD})$, and $28.4 \pm 1.25 \%$ ADF $( \pm \mathrm{SD})$ in the DM. Predicted $\mathrm{OM}$ digestibility was $65.0 \pm 2.65 \%( \pm \mathrm{SD})$, with $\mathrm{ME}$ averaging $9.1 \pm 0.41( \pm \mathrm{SD}) \mathrm{MJ} / \mathrm{kg}$ of $\mathrm{DM}$.

Dry matter intakes were strongly related to BW $\left(\mathrm{R}^{2}\right.$ $=0.75)$, feed conversion efficiency, feed/gain $\left(\mathrm{R}^{2}=\right.$ $0.34)$, and weekly-to-daily gain $\left(\mathrm{R}^{2}=0.18\right)$. Multiple regression analysis of factors contributing to variation in feed conversion efficiency showed that $43 \%$ of variation was explained by RFI and year; $66 \%$ by daily gain and year; and $71 \%$ by RFI, daily gain, and year (all $P$ $<0.001)$. Daily gain averaged $0.88 \pm 0.13( \pm \mathrm{SD})$ and the breeding worth of the 1,052 heifers evaluated had a mean value of $147 \pm 17.2( \pm \mathrm{SD})$.

Characteristics of divergent groups (averaged) from each cohort (Table 4) were similar to those for all animals evaluated (Table 3). Data for each cohort demonstrated similar patterns for BW, intakes, daily gain, and breeding worth of the most and least efficient groups (Table 5).

The $10 \%$ most and $10 \%$ least efficient groups of animals from the RFI determination have been retained for future measurements, with details such as daily gain and intake summarized in Table 5. When the most efficient and least efficient 10\% ( $\mathrm{n}=208)$ groups were compared, no differences were observed in daily gains $(\mathrm{kg})$, which averaged $0.88 \pm 0.15( \pm \mathrm{SD})$ and $0.88 \pm$ 0.12 ( $\pm \mathrm{SD} ; P=0.568)$, respectively. The divergence between actual and fitted intakes was $1.46 \mathrm{~kg}$ of DM/d (Table 5), with efficient animals eating $0.77 \mathrm{~kg}$ of $\mathrm{DM} / \mathrm{d}$ less than predicted, and inefficient eating being, on average, $0.69 \mathrm{~kg}$ of $\mathrm{DM} / \mathrm{d}$ more than predicted. Intakes expressed as $\mathrm{g}$ of $\mathrm{DM} / \mathrm{BW}^{0.75}$ averaged 114 and 142 for the respective groups. The average BW of both groups were similar, as were values for breeding worth, averaging 148 (Table 5).

\section{DISCUSSION}

The procurement and screening of more than 1,000 dairy heifers has identified substantial divergence in RFI. The main difference between this trial and most published reports has been the use of alfalfa cubes as a sole diet during the assessment period, in contrast to rations based on silages, with various proportions of grain (for example, 70-80\% grain for finishing beef: Richardson and Herd, 2004; Nkrumah et al., 2006; 50\% grain

Table 4. Predicted cohort means for daily gain, mean feed DMI, and divergence for residual feed intake of the most and least efficient $10 \%$ individuals ${ }^{1}$ determined over a $49-d$ measurement period

\begin{tabular}{|c|c|c|c|c|c|c|c|}
\hline Item & \multicolumn{5}{|c|}{ Cohort } & Mean & $\mathrm{SED}^{2}$ \\
\hline Mid-trial $\mathrm{BW}^{3}(\mathrm{~kg})$ & 241 & 172 & 195 & 181 & 191 & 196 & 3.47 \\
\hline Mid-trial $\mathrm{BW}^{3}\left(\mathrm{~kg}^{0.75}\right)$ & 61.1 & 47.4 & 52.1 & 49.3 & 51.4 & 52.2 & 0.70 \\
\hline Intake mid-trial $(\mathrm{kg} / \mathrm{d})$ & 8.07 & 5.62 & 6.94 & 6.33 & 6.59 & 6.71 & 0.130 \\
\hline
\end{tabular}

${ }^{1}$ One hundred and four efficient and 104 inefficient animals.

${ }^{2}$ Standard error of the difference. Cohort effects all significantly different $(P<0.001)$ except actual-fitted DMI $(P=0.992)$.

${ }^{3}$ Initial and mid-trial BW were derived from fitted regressions over time for each animal. 
Table 5. Predicted means of the most and least efficient $10 \%$ individuals $^{1}$ for daily gain, mean feed DMI, and divergence for residual feed intake (RFI) determined over a 49-d measurement period

\begin{tabular}{|c|c|c|c|c|}
\hline \multirow[b]{2}{*}{ Item } & \multicolumn{2}{|c|}{ Efficiency } & \multirow[b]{2}{*}{$\mathrm{SED}^{2}$} & \multirow[b]{2}{*}{$P$-value } \\
\hline & Bottom $10 \%$ & Top $10 \%$ & & \\
\hline Age at start $(\mathrm{d})$ & 217 & 217 & 1.2 & 0.641 \\
\hline Breeding worth & 148 & 148 & 2.12 & 0.751 \\
\hline Mid-trial $\mathrm{BW}^{3}(\mathrm{~kg})$ & 196 & 195 & 2.20 & 0.526 \\
\hline Mid-trial $\mathrm{BW}^{3}\left(\mathrm{~kg}^{0.75}\right)$ & 52.4 & 52.2 & 0.442 & 0.504 \\
\hline Intake mid-trial (kg/d) & 7.45 & 5.96 & 0.097 & $<0.001$ \\
\hline Fitted intake mid-trial ${ }^{4}$ & 6.76 & 6.74 & 0.087 & 0.620 \\
\hline RFI & 0.69 & -0.77 & 0.043 & $<0.001$ \\
\hline Daily gain $(\mathrm{kg})$ & 0.873 & 0.876 & 0.018 & 0.989 \\
\hline Intake $/ \mathrm{kg}$ of BW gain $(\mathrm{kg})$ & 8.63 & 6.88 & 0.147 & $<0.001$ \\
\hline
\end{tabular}

for growing bulls: Lancaster et al., 2009; but sometimes only 15 to $20 \%$ grain in growing heifers: Shaffer et al., 2011). It was considered essential to select animals that will graze forage over their lifetime using a forage diet. However, divergence for gain in these Holstein-Friesian heifers $(21.6 \%$ between the means of the most and least efficient $10 \%$ of the measured population) appears to be similar to reports from young and finishing beef animals (Lancaster et al., 2009; Shaffer et al., 2011) and dairy heifers (Williams et al., 2011), which have similar ranges in RFI (typically 17 to $28 \%$ ) with the $10 \%$ extremes.

Other attempts have been made to evaluate RFI in cattle using forage diets. Herd et al. (2002) and Meyer et al. (2008) have measured RFI in steers and cows previously selected for divergence, under forage feeding, and although the trait appeared to have been conserved, in both cases it was difficult to demonstrate statistical significance between selections. For example, Meyer et al. (2008) reported numerical differences of 21 and $11 \%$ for grazing beef cows and cow-calf pairs, respectively, but low animal numbers and especially the difficulty in accurate determination of intakes limited their ability to detect differences. The success or otherwise of using RFI for gain as a proxy for lactation is subject of ongoing research.

\section{RFI and Ranking for Production}

Selection of appropriate animals was an important aspect of this research, and the intention was to identify divergent individuals from a population having the genetic capability for profitability that was equivalent to the national herd average in 2018. This was undertaken by selecting animals on the basis of breeding worth. The breeding worth ranking applies to individual cow production under competitive grazing, typical of the New Zealand pastoral system, and is the basis upon which genetic improvements have been achieved. The absence of a significant correlation between breeding worth and ranking for RFI $(\mathrm{r}=-0.02)$ suggests that the current selection criteria for breeding worth do not identify individuals differing in efficiency of feed utilization. The breeding worth values were identical for the most and least efficient groups (147; Table 3), suggesting an equivalent profitability value of divergent groups for milk production, but efficient individuals will achieve a similar production from substantially less feed.

Although breeding worth ranking has improved dairy cow profitability, one measure that is notably absent from the criteria is individual cow intakes. Breeding worth is determined for cows grazing pasture, which accounts for at least $90 \%$ of their diet. Pasture grazing is intensive, with a new allocation given after each morning and afternoon milking (Holmes et al., 2002), and cows are required to graze to a low pasture residual DM to maintain herbage quality and fully utilize available feed (Holmes and Roche, 2007). Thus, ad libitum intakes are rarely achieved and cows are not fully fed. Under competitive grazing, individuals with a high breeding worth may also have the highest intakes, achieved through aggressive eating, or by being milked early and reaching the paddock before the majority of the herd. Future measurements will need to assess the ability of efficient cows (low RFI) to achieve high intakes and milksolids (fat + protein) production under controlled competitive grazing.

Genetic improvement of the New Zealand dairy herd is biased toward production characteristics (especially of protein) but includes some measures of welfare. Milk SCC are a component of the index, as well as longevity, 
which is linked with fertility. Under a seasonal grazing system, it is essential that cows are pregnant within 12 wk of parturition (Harris and Kolver, 2001) and poor reproductive performance is less tolerated than in confinement systems where feed supply is not dominated by seasonality and pasture growth. Future measurements with divergent individuals will include BW loss postpartum, which can be linked to poor reproductive performance (Roche et al., 2007), poor health, and is metabolically inefficient (Coffey et al., 2004). Heifers identified as efficient for BW gain (low RFI) should also mobilize less BW compared with the herd average.

\section{System Performance}

The design and operation of the facility was based on preliminary screening to establish the time required for individual animals to eat their daily allowance of the cubes. This was followed by a re-evaluation of animal numbers per feeding station, because animals did use the feeding station for most of the available time (about $22.5 \mathrm{~h} / \mathrm{d}$ ). Decreasing the animal number to 6/ pen increased eating time, but not voluntary intakes, so providing a single feeding station for 8 animals was unlikely to restrict intakes and daily gain.

Delays occurred in achieving routine reliable data at commissioning, which accounted for the heavier animals in cohort 1, and they were in the facility for $90 \mathrm{~d}$. Data acquisition was very good and level 3 , and occasionally level 4 data, were examined daily to ensure overall reliability, which averaged $98.7 \%$ of potential capture.

\section{Suitability of Alfalfa Cubes for Screening}

The choice of alfalfa cubes as a sole diet enabled accurate measurement of intakes, which would not have been possible with fresh forages. Cut pasture is bulky, with a DM content of 13 to $25 \%$ under New Zealand conditions, and it loses moisture and heats rapidly once cut. In contrast, the alfalfa cubes were easily handled, and particle length was sufficiently long to achieve normal digestion, as judged by fecal consistency. Forage diets are associated with very different digestion dynamics, compared with diets containing grain (Allen, 1996; Waghorn, 2002), especially in terms of bulk and molar ratios of VFA. It was essential that screening was undertaken using diets with similar physical characteristics as the animals' lifetime diet, and this was achieved to some extent with the alfalfa cubes. However, the predicted OM digestibility and ME content of the $\mathrm{DM}(65 \%$ and $9.1 \mathrm{MJ} / \mathrm{kg}$ of $\mathrm{DM}$, respectively) were well below values for ryegrass-dominant dairy pastures, which have digestibilities ranging between 70 and $80 \%$ and $\mathrm{ME}$ values of 10.5 to $12.0 \mathrm{MJ} / \mathrm{kg}$ of $\mathrm{DM}$ (Waghorn et al., 2007).

The most apparent difference between cubes and a fresh-pasture diet was the low volume required to be consumed, with $84.5 \% \mathrm{DM}$ in the cubes versus 12 to $20 \%$ DM typical of fresh pasture (Waghorn et al., 2007). This enabled a more rapid consumption of feed than would occur at grazing, averaging about $2.8 \mathrm{~h} / \mathrm{d}$ compared with 8 to $9 \mathrm{~h}$ at pasture (Thorne et al., 2003). Analysis of data from cohort 2b (Green et al., 2011) showed that efficient animals spent less time eating $(P$ $<0.05)$ and had fewer meals than inefficient individuals (4.03 vs. 4.85$)$.

The CP concentration in cubes $(18.7 \%$ of DM) was lower than values typical of ryegrass $(18-26 \%)$ and the NDF concentration ( $45.8 \%$ of DM) was higher than 35 to $45 \%$ typical of good quality ryegrass (Holmes et al., 2002; Waghorn et al., 2007) Despite the poor quality of the cubes relative to ryegrass pasture, the calves achieved high rates of gain, slightly exceeding recommended rates of 0.6 to $0.8 \mathrm{~kg} / \mathrm{d}$ for young HolsteinFriesian heifers raised in pasture (Macdonald et al., 2005, 2007).

\section{CONCLUSIONS}

A facility was designed to measure intakes and daily gain of Holstein-Friesian heifers, enabling alfalfa cubes to be fed for the determination of RFI. Data acquisition exceeded $98 \%$ of potential capture and 3 times weekly weighing enabled the evaluations to be completed in $49 \mathrm{~d}$. Alfalfa cubes were given as a sole diet because roughage (grazed ryegrass) accounts for $90 \%$ of the diet of New Zealand dairy cows (the remainder being predominantly silage). Average daily gain of the 5 to 9 -mo animals $(0.88 \mathrm{~kg})$ was similar for high and low RFI selections. Intakes for the $10 \%$ efficient and 10\% inefficient extremes differed by $21.6 \%$, which is similar to published results from beef animals fed diets comprising grain and silages. The RFI measured in this study was not related to breeding worth, which is the system used in New Zealand for herd improvement.

\section{ACKNOWLEDGMENTS}

The authors thank Barbara Dow (Dairy NZ, Hamilton, New Zealand) for statistical analysis and Dairy NZ technical staff in Newstead (Hamilton, New Zealand) and at the Westpac Taranaki Agricultural Research Station research facilities in Hawera (New Zealand), where animal feeding and measurements were carried out. Funding was provided by the Foundation for Research, Science and Technology (FRST, Wellington, 
New Zealand); DairyNZ Ltd. (Waikato, New Zealand); LIC (Waikato, New Zealand); and Trade and Enterprise (New Zealand).

\section{REFERENCES}

AEU (Animal Evaluation Unit). 2011 Animal Evaluation. Accessed April 2011. http://www.aeu.org.nz.

Allen, M. S. 1996. Physical constraints on voluntary intake of forages by ruminants. J. Anim. Sci. 74:3063-3075.

Archer, J. A., R. F. Arthur, R. M. Herd, P. F. Parnell, and W. S. Pitchford. 1997. Optimum postweaning test for measurement of growth rate, feed intake, and feed efficiency in British breed cattle. J. Anim. Sci. 75:2024-2032.

Arthur, P. F., and R. M. Herd. 2005. Efficiency of feed utilisation by livestock-Implications and benefits of genetic improvement. Can. J. Anim. Sci. 85:281-290.

Barea, R., S. Dubois, H. Gilbert, P. Sellier, J. van Milgen, and J. Noblet. 2010. Energy utilization in pigs selected for high and low residual feed intake. J. Anim. Sci. 88:2062-2072.

Basarab, J. A., M. A. Price, J. L. Aalhus, E. K. Okine, W. M. Snelling, and K. L. Lyle. 2003. Residual feed intake and body composition in young growing cattle. Can. J. Anim. Sci. 83:189-204.

Berry, D. P. 2009. Improving feed efficiency in cattle with residual feed intake. Pages 67-99 in Recent Advances in Animal Nutrition 2008. P. C. Garnsworthy and J. Wiseman, ed. Nottingham Univ. Press, Nottingham, UK.

Coffey, M. P., G. Simm, J. D. Oldham, W. G. Hill, and S. Brotherstone. 2004. Genotype and diet effects on energy balance in the first three lactations of dairy cows. J. Dairy Sci. 87:4318-4326.

DairyBase. 2011. DairyNZ Economic Survey 2009-10. Accessed June 7, 2011. http://www.dairynz.co.nz/file/fileid/37217. DairyBase, Hamilton, New Zealand.

GreenT. C.WaghornG. C.BeausoleilN. J.MacdonaldK. A. 2011. Feeding behaviour differs between dairy calves selected for divergent feed conversion efficiency. Proc. N.Z. Soc. Anim. Prod. 71:281-285.

Harris, B. L., and E. S. Kolver. 2001. Review of Holsteinization in intensive pastoral dairy farming in New Zealand. J. Dairy Sci. 84(E Suppl.):E56-E61.

Herd, R. M., and P. F. Arthur. 2009. Physiological basis for residual feed intake. J. Anim. Sci. 87:E64-E71.

Herd, R. M., R. S. Hegarty, R. W. Dicker, J. A. Archer, and P. F. Arthur. 2002. Selection for residual feed intake improves feed conversion ratio on pasture. Anim. Prod. Aust. 24:85-88.

Herndon, R. S. 2010. Comparison of the economics and costs of producing milk on a conventional vs. grass-based "New Zealand style" dairies in Mississippi. J. Dairy Sci. 93(E-Suppl. 1):243. (Abstr. 235)

Holmes, C. W., I. M. Brookes, D. J. Garrick, D. D. S. MacKenzie, T. J. Parkinson, and G. W. Wilson. 2002. Milk Production From Pasture: Principles and Practices. Massey University, Palmerston North, New Zealand.

Holmes, C. W., and J. R. Roche. 2007. Pastures and supplements in dairy production systems. Pages 221-242 in Pasture and Supplements for Grazing Animals. New Zealand Society of Animal Production Occasional Publication No. 14. P. V. Rattray, I. M. Brookes, and A. M. Nichol ed. New Zealand Society of Animal Production, Hamilton, New Zealand.

Johnson, D. E., C. L. Ferrell, and T.G. Jenkins. 2003. The history of energetic efficiency research: where have we been and where are we going? J. Anim. Sci. 81(E Suppl. 1):E27-E38.

Kearney, G. A., B. W. Knee, J. F. Graham, and S. A. Knott. 2004. The length of test required to measure liveweight change when testing for feed efficiency in cattle. Aust. J. Exp. Agric. 44:411-414.

Kolver, E. S., and L. D. Muller. 1998. Performance and nutrient intake of high producing Holstein cows consuming pasture and total mixed ration. J. Dairy Sci. 81:1403-1411.

Kolver, E. S., J. R. Roche, M. J. de Veth, P. L. Thorne, and A. R. Napper. 2002. Total mixed rations versus pasture diets: Evidence for a genotype $\mathrm{x}$ diet interaction in dairy cow performance. Proc. N.Z. Soc. Anim. Prod. 62:246-251.

Lancaster, P. A., G. E. Carstens, F. R. B. Ribeiro, L. O. Tedeschi, and D. H. Crews. 2009. Characterization of feed efficiency traits and relationships with feeding behavior and ultrasound carcass traits in growing bulls. J. Anim. Sci. 87:1528-1539.

LIC (Livestock Improvement Corporation). 2009. New Zealand Dairy Statistics 2008-09. Accessed April 2011. http://www.lic.co.nz/ pdf/DAIRY_STATISTICS_08-09.pdf.

Lucy, M. C., G. A. Verkerk, B. E. Whyte, K. A. Macdonald, L. Burton, J. R. Roche, and C. W. Holmes. 2009. Somatotropic axis components and nutrient partitioning in genetically diverse dairy cows managed under different feed allowances in a pasture system. J. Dairy Sci. 92:526-539.

Macdonald, K. A., L. R. McNaughton, G. A. Verkerk, J. W. Penno, L. J. Burton, D. P. Berry, P. J. S. Gore, J. A. S. Lancaster, and C. W. Holmes. 2007. A comparison of three strains of Holstein-Friesian cows grazed on pasture: Growth, Development and puberty. J. Dairy Sci. 90:3993-4003.

Macdonald, K. A. J. W. Penno, A. M. Bryant, and J. R. Roche. 2005 Effect of feeding level pre- and post-puberty and body weight at first calving on growth, milk production and fertility in grazing cows. J. Dairy Sci. 88:3363-3375.

Macdonald, K. A., G. A. Verkerk, B. S. Thorrold, J. E. Pryce, J. W. Penno, L. R. McNaughton, L. J. Burton, J. A. S. Lancaster, J. H. Williamson, and C. W. Holmes. 2008. A comparison of three strains of Holstein-Friesian grazed on pasture and managed under different feed allowances. J. Dairy Sci. 91:1693-1707.

McNaughton, L. R., and J. E. Pryce. 2007. Metabolic feed efficiencyOpportunities for selection in dairy cows. Proc. N.Z. Soc. Anim. Prod. 67:392-398.

Meyer, A. M., M. S. Kerley, and R. L. Kallenbach. 2008. The effect of residual feed intake classification on forage intake by grazing beef cows. J. Anim. Sci. 86:2670-2679.

Nielsen, M. K., and J. M. McDonald. 2006. Resumed divergent selection for heat loss in mice: Selection applied and response in heat loss and feed intake. Proc. 8th World Congress on Genetics Applied to Livestock Production, Belo Horizonte, MG, Brazil. CDROM communication 14-04.

Nkrumah, J. D., E. K. Okine, G. W. Mathison, K. Schmid, C. Li, J. A. Basarab, M. A. Price, Z. Wang, and S. S. Moore. 2006. Relationships of feedlot feed efficiency, performance, and feeding behavior with metabolic rate, methane production, and energy partitioning in beef cattle. J. Anim. Sci. 84:145-153.

Primary Industries Standing Committee. 2007. Nutrient Requirement of Domesticated Ruminants. CSIRO Publishing, Collingwood, Australia.

Pryce, J. E., J. Arias, P. J. Bowman, S. R. Davis, K. A. Macdonald, G. C. Waghorn, W. J. Wales, Y. J. Williams, R. J. Spelman, and B. J. Hayes. 2012. Accuracy of genomic predictions of residual feed intake and 250 day bodyweight in growing heifers using 625,000 SNP markers. J. Dairy Sci. doi:10.3168/jds.2011-4628.

Richardson, E. C., and R. M. Herd. 2004. Biological basis for variation in residual feed intake in beef cattle. 2. Synthesis of results following divergent selection. Aust. J. Exp. Agric. 44:431-440.

Roche, J. R., K. A. Macdonald, C. R. Burke, J. M. Lee, and D. P. Berry. 2007. Associations among body condition score, body weight, and reproductive performance in seasonal-calving dairy cattle. J. Dairy Sci. 90:376-391.

Shaffer, K. S., P. Turk, W. R. Wagner, and E. E. D. Felton. 2011. Residual feed intake, body composition, and fertility in yearling beef heifers. J. Anim. Sci. 89:1028-1034.

Thorne, P., J. G. Jago, E. S. Kolver, and J. R. Roche. 2003. Diet and genotype affect feeding behaviour in Holstein-Friesian dairy cows during late lactation. Proc. N.Z. Soc. Anim. Prod. 63:124-127.

Van Eerden, E., H. Van Den Brand, H. K. Parmentier, M. C. M. De Jong, and B. Kemp. 2004. Phenotypic selection for residual feed intake and its effect on humoral immune responses in growing layer hens. Poult. Sci. 83:1602-1609.

Veerkamp, R. F., and G. C. Emmans. 1995. Sources of genetic variation in energetic efficiency of dairy cows. Livest. Prod. Sci. 44:87-97. 
WaghornG. C. 2002. Can forages match concentrate diets for dairy production? Proc. N. Z. Soc. Anim. Prod. 62:261-266.

Waghorn, G. C., J. L. Burke, and E. S. Kolver. 2007. Principles of feeding value. Pages 35-59 in Pasture and Supplements for Grazing Animals P. V. Rattray, I. M. Brookes, and A. M. Nicol, ed. New Zealand Society of Animal Production Occasional Publication No. 14. New Zealand Society of Animal Production, Hamilton New Zealand.

Waghorn, G. C., and R. J. Dewhurst. 2007. Feed efficiency in cattleThe contribution of rumen function. Pages 111-123 in Meeting the challenges for pasture-based dairying. Proc. 3rd Dairy Sci- ence Symposium, University of Melbourne. D. F. Chapman, D. A. Clark, K. L. Macmillan, and D. P. Nation, ed. National Dairy Alliance.

Williams, C. B., and T. G. Jenkins. 2006. Impact of selection for feed efficiency on beef life cycle performance. CD-ROM: Proc. 8th World Congress on Genetics Applied to Livestock Production, Belo Horizonte, MG, Brazil. FAO, Rome, Italy.

Williams, Y. J., J. E. Pryce, C. Grainger, W. J. Wales, N. Linden, M. Porker, and B. J. Hayes. 2011. Variation in residual feed intake in Holstein-Friesian dairy heifers in southern Australia. J. Dairy Sci. 94:4715-4725. 